\title{
TEACHERS' USE AND ACCEPTANCE OF GAMIFICATION AND SOCIAL NETWORKING FEATURES OF AN OPEN REPOSITORY
}

\author{
Beatriz.delos Arcos [b.de-los-arcos@open.ac.uk], The Open University, United Kingdom,Bram Faems \\ [bram@klascement.net], Klascement, Belgium, Anna Comas-Quinn [anna.comas-quinn@open.ac.uk.], Hélène \\ Pulker[belene.pulker@open.ac.uk], The Open University, United Kingdom
}

\begin{abstract}
The affordance of social interaction has been a part of open online repositories of teaching and learning resources for nearly two decades. Repositories are built not only to collect and disseminate materials, but enable users to collaborate and review, comment on and rate the content they access. However, research indicates that (a) most users do not participate in this type of generative use, and (b) the possibility of social interaction does not necessarily signal active participation in social interaction. In recent years the positive effects of gamification and social networking elements on user engagement have come to the fore in educational settings. From this stance, a quantitative study was conducted to assess users' acceptance of the existing game mechanics of a large national repository of educational resources, their attitudes towards the inclusion of extra features, and teachers' motivation to share openly. Our results indicate that teachers do not see open repositories as social networks, but as libraries of resources, and are likely to share if rewarded by intrinsic rather than extrinsic factors.
\end{abstract}

\section{Abstract in Spanish}

La posibilidad de interacción social viene formando parte de los repositorios abiertos de recursos para la enseñanza y el aprendizaje durante casi dos décadas. Los repositorios existen no sólo para recoger y diseminar materiales educativos, sino que también permiten a los usuarios colaborar, comentar y evaluar el contenido al que acceden. Sin embargo, estudios de investigación señalan que (a) la mayoría de usuarios no participan en este tipo de comportamiento generativo, y (b) la oportunidad de interacción social no conlleva necesariamente la activa participación en la interacción social. En los últimos años el impacto positivo de la ludificación y otros elementos característicos de las redes sociales sobre el compromiso del usuario han pasado a un primer plano en contextos educativos. Es por eso que se realiza este estudio cuantitativo para determinar cómo los usuarios de un repositorio nacional de recursos didácticos valoran las estrategias de juego del sistema, su actitud ante la inclusión de nuevas estrategias, y qué les motiva a compartir abiertamente. Los resultados indican que los profesores no consideran los repositorios abiertos como redes sociales sino como bibliotecas de recursos, y es más probable que compartan si se les premia con factores intrínsecos y no extrínsecos.

\section{Abstract in Dutch}

Sociale interactie heeft de voorbije twee decennia opportuniteiten geboden binnen open online repositories voor leermiddelen voor het onderwijs. Repositories zijn niet alleen gebouwd om materialen te verzamelen en te verspreiden, maar ook om gebruikers in staat te stellen om samen te werken aan inhouden en deze te becommentariëren en te beoordelen. Echter, uit onderzoek blijkt dat (a) de meeste gebruikers dergelijk generatief gedrag niet stellen, en (b) de mogelijkheid tot sociale interactie niet noodzakelijk leidt tot deelname aan sociale interactie. In de afgelopen jaren kwamen de positieve effecten van gamification en social networking elementen op 
betrokkenheid van gebruikers naar voren in educatieve contexten. Vanuit dit standpunt, werd een kwantitatief onderzoek uitgevoerd om aanvaarding te evalueren van bestaande 'game mechanics' bij gebruikers van een grote repository van educatieve leermiddelen, hun houding ten opzichte van het opnemen van extra mogelijkheden, en leraren hun motivatie om te delen. Onze resultaten geven aan dat leraren open repositories niet als sociale netwerken zien, maar als bibliotheken van middelen, en ze meer geneigd zijn te delen door intrinsieke in plaats dan extrinsieke factoren.

\section{Abstract in French}

L'accessibilité à l'interaction sociale est une composante clé des archives ouvertes en ligne de ressources d'enseignement et d'apprentissage depuis près de deux décennies. Ces archives sont conçues non seulement pour rassembler et diffuser du matériel, mais aussi afin de permettre aux utilisateurs de collaborer, réviser, commenter et évaluer le contenu auquel ils ont accès. Cependant, la recherche indique que (a) la plupart des utilisateurs ne participent pas à ce type de génération de contenu, et (b) la possibilité d'une interaction sociale ne signifie pas forcément une participation active à cette interaction sociale. Au cours des dernières années, les effets positifs de la ludification et du réseautage social sur la participation des utilisateurs ont été mis en évidence dans les milieux éducatifs. Par conséquent, une étude quantitative a été menée afin d'évaluer l'acceptation par les utilisateurs de la mécanique de jeu en évidence dans une archive nationale conséquente de ressources pédagogiques, leurs attitudes à l'égard de l'inclusion de fonctionnalités supplémentaires, et la motivation des enseignants à partager ouvertement. Nos résultats indiquent que les enseignants ne considèrent pas les archives ouvertes en tant que réseaux sociaux, mais comme des bibliothèques de ressources, et sont susceptibles de partager si la récompense est plutôt de nature intrinsèque qu'extrinsèque.

Keywords: open repositories, social networking, gamification, open educational resources

\section{Introduction and Literature Review}

The affordance of social interaction has been a part of open online repositories of teaching and learning resources for nearly two decades. Repositories are built not only to collect and disseminate materials, but enable users to collaborate and review, comment on and rate the content they access (Atenas \& Havemann, 2013). However, research indicates that (a) the most common behaviour on open repositories is non-generative use (Pynoo, Tondeur, van Braak, Duyck, Sijnave, \& Duyck, 2012; Sabourin, Kosturko, \& McQuiggan, 2014), and (b) the possibility of social interaction does not necessarily equate active participation in social interaction (Clements, Pawlowski, \& Manouselis, 2015). In recent years, gamification, or the implementation of game features in non-game contexts, and social networking elements such as likes, reactions and scores have been hyped as a technique to channel user engagement, piquing the interest of academic communities beyond success in marketing contexts (Zourou \& Lamy, 2013; Zourou, 2016): can the positive effects of game mechanics be transferred to educational settings?

\section{Users' non-generative behaviour in open repositories}

Aware of the lack of a sharing culture among their teaching staff, in 2010 the Department of Languages at The Open University, UK launched LORO (Languages Open Resource Online http://loro.open.ac.uk), a platform containing language teaching resources available to download and reuse, which also facilitates users depositing their own materials. The initiative was boosted by the findings of a survey of educators' attitudes towards sharing -a very small fraction of respondents expressed they disliked making their resources public or did not want other people to use them (Comas-Quinn, Beaven, Pleines, Pulker, \& de los Arcos, 2011). In the year that followed the birth of LORO, analytics recorded 1.5 million visits to the site, 2,500 deposits and 50K+ downloads (Comas-Quinn \& Fitzgerald, 2013); since then, the most current data show that 
the number of visitors per year has levelled off at circa $75 \mathrm{~K}$, while the amount of uploads remains close to the original 2,500.

HumBox (http://humbox.ac.uk) is a very similar repository of digital humanities resources lead by the University of Southampton. In an impact study based on a small survey of users it was found positive that the percentage of educators who uploaded resources did not differ much from the percentage of those who downloaded them, even if a majority of the latter did not go on to use these materials in class. More importantly, the discovery that $80 \%$ of the sample surveyed had not commented or reviewed a resource prompted the authors' reflection to further develop said functionality, although not their reassessment of the repository as "the hub of a community of humanities professionals who are engaged in re-using and reviewing each other's resources" (Borthwick, Millard, \& Howard, 2011; p.2).

A larger study conducted at the University of Ghent looked at the usage data of KlasCement (https://www.klascement.be), an educational portal in Belgium, to assess its acceptance by teachers. Looking at logins, uploads, downloads, reactions and page views, four types of users were identified -new, light, medium and heavy, before determining that "the average teacher downloads at least one item per login, but contributes only very rarely" (Pynoo et al., 2012; p.1312).

This preference for consuming rather than contributing information is not exclusive to users of small repositories. As of February 2015, their newsletter informed that MERLOT (https://www.merlot.org) contained over $62 \mathrm{~K}$ items in its collection, viewed by over half a million people, who however had only peer-reviewed 3,980, and commented on 5,712 of them.

These data coincide with findings from research into the difference in attitudes towards, and perceptions of, use of open educational resources (OER) between educators in the Global South and Global North (de los Arcos \& Weller, in press). The analysis of responses to a questionnaire comprising thousands of participants shows that an overarching majority had never added a resource to a repository, or added comments regarding the quality of a resource or suggesting ways of using a resource.

\section{Motivation to share}

In an exploration of what triggers individuals to give away their knowledge for free, quantitative research (OECD, 2007) shows that producers of open content are most concerned with being acknowledged as the creator of a resource when it is used, adapted or changed, and having its quality reviewed, but give little importance to being personally rewarded - either financially or through promotion, awards, etc. Atenas, Havemann, and Priego (2014) also identify clear attribution of resources as a factor influencing the successful development of repositories, and Phalachandra and Abeywardena (2016) cite lack of rewards or recognition amongst the lowest barriers to academics developing and using open content.

All these studies present the views of those whose professional practice evolves around a certain degree of openness. van Acker, van Buuren, Kreijns, and Vermeulen (2013), however, looked at rewards as predictors of teachers' intentions to share, considering altruism, reputation and reciprocity. They found that sharing in itself motivates teachers to share; that respect shown by other teachers when sharing resources discourages sharing; and that other teachers sharing has no impact on one's intention to share. For Tseng and Kuo (2014), knowledge sharing in online communities of practice is determined by teachers' altruistic motives (knowledge-giving) and their performance expectation (knowledge-receiving). 


\section{Gamification and Fogg's Model of Human Behaviour}

Gamification has been defined as "incorporating game elements into a non-gaming software application to increase user experience and engagement" (Domínguez et al., 2013; p.381); points, badges and leaderboards have been identified as the most popular game mechanisms (Dicheva, Dichev, Agre, \& Angelova, 2015). Despite being an emerging area, several reviews of empirical studies into the effects of gamification have already been published. Hamari, Koivisto, and Sarsa (2014) concluded that the positive influence of gamification on motivation is dependent on context and user qualities. Dicheva et al. (2015) exclusively appraised research that applied game elements in educational settings to concur on their potential to improve learning. More recently, Nacke and Deterding (2017) have proclaimed the maturity of gamification as a research field, from theory-less to theory-driven scholarship. One such approach has informed our investigation. Fogg's model of human behaviour (FBM) explains that for a behaviour to occur, a person "must (1) be sufficiently motivated, (2) have the ability to perform the behavior, and (3) be triggered to perform the behavior" (Fogg, 2009). This led to our hypothesis that gamification and social networking elements in an OER repository could act as a trigger to the desired generative behaviour. Before implementing such elements, a needs analysis was performed to evaluate users' approval of these changes.

This paper makes a contribution to the field by providing empirical evidence of users' acceptance of social network and gamification features of open repositories, in order to assess their capacity to drive engagement with open resources.

In the following sections we set up our research questions; explain the methodology employed; present quantitative results; discuss our findings; and outline future research.

\section{Research questions}

The present study was conducted within the context of the European Commission co-founded ExplOERer Project (http://www.exploerer.gu.se) to promote open educational resources (OER) sustainability through OER adoption and reuse in educators' professional practice. One of the project outcomes sought out to better understand the role of social networking and gamification features in online open repositories, and examine users' acceptance of these features as incentive systems to use and reuse OER. To this aim, project partners KlasCement carried out quantitative research to address the following questions:

- How do users of KlasCement perceive, and engage with, the existing social networking features of the portal?

- How would users react to the inclusion of additional gamification and social networking features in order to drive further engagement?

\section{Materials and method}

\section{KlasCement and its points system}

KlasCement $(\mathrm{KC})$ is a free online platform for educators to share educational resources for students of all ages. Users can upload materials they have created themselves, as well as sharing interesting websites, useful apps, multimedia or practical examples. All resources are validated by a group of moderators who decide on their admission based on quality criteria. A personal profile enables users to connect with each other; these profile pages contain their contact details on different social networks, and track their activity on KC -My Resources, My Favourites, My Scores. 
The points system offers individuals a simplified view on their use of the portal. Upon registration, users receive 1000 points. Receptive behaviour (viewing educational resources) decreases their number of points. They can view 500 resources before reaching 0 , at which point they cannot see any new resources anymore. Generative behaviour (rating resources, writing a comment, or adding resources) increases their total score. The points system is thus a way to nudge users into providing peer reviews via scores and reactions, and to share their own materials.

\section{Data collection and instrument}

In 2016 a sample of users of KlasCement were invited to complete a survey distributed via email. The survey was structured in four sections. The first set of items was designed to collect selfreported data on perceived usefulness and perceived ease of use of the portal, and teachers' purposes for accessing $\mathrm{KC}$. The second section of the questionnaire asked respondents to selfreport on the frequency of certain behaviour i.e. looking at user profile pages, reading comments, etc. A third cluster of items set out to investigate users' attitudes towards the inclusion of specific gamification and social networking features on their profile pages, namely markers of recent activity, badges, and challenges to promote engagement. Finally, the authors devised a set of statements, informed by Goal Theory and adapted from the Inventory of School Motivation (McInerney et al., 1997; McInerney \& Ali, 2016), to determine teachers' motivation to share on KlasCement. These statements were written to relate to mastery, ego, social solidarity and extrinsic goals, each comprised of two elements as follows:

- Mastery goals: task involvement ("I am motivated to share on $\mathrm{KC}$ when I get valuable feedback on my resources to improve them") and striving for excellence ("Because this extra effort makes me feel a professional teacher").

- Performance goals: competitiveness ("When I can view the popularity of my contributions in a leaderboard") and power/group leadership ("When it can lead to interesting career opportunities (such as giving workshops, having my resources published, etc.").

- Social solidarity goals: affiliation ("When I am able to collaborate with other teachers") and social concern ("When I am well informed about how many teachers I've helped by sharing my resources").

- Extrinsic goals: recognition ("When I get a lot of likes and positive comments by other users") and token rewards ("When I can exchange the KC-points that I earn for an actual prize (books, cinema tickets, coupons, etc.").

All variables were scored on a 4-point Likert scale anchored between $0=$ strongly disagree and $3=$ strongly agree, or $0=$ never and $3=$ often.

The instrument was originally written in English, then translated into Dutch, and piloted on two occasions: first with a group of $\mathrm{KC}$ staff, and secondly with a small group of primary school teachers. Minor changes were suggested and implemented.

\section{Sample}

The authors employed purposive sampling and selected as survey respondents KlasCement users who (a) were Flemish teachers and (b) had been active in the repository during the previous three months. In addition to demographic data (gender and age), use data were extracted from the portal's database regarding the number of logins, pages viewed, downloads, uploads (i.e. a work sheet, a link to a website, etc.), comments (i.e. reactions to uploaded material) and scores of each individual. The scoring system served as a representation of users' behaviour on $\mathrm{KC}$ on the premise that receptive use leads to the loss of points and generative use leads to an increase in 
points. Because individuals with a low number of points use the repository without contributing anything back, and those with a high number of points interact and add resources, it was hypothesized that the responses of the two groups would differ, and allow for comparative analysis.

In the first instance, the 500 teachers with the highest scores and the 500 with the lowest scores were sent a request to complete the survey via email. As a result of an insufficient return of responses, the invitation was extended to a further 1,500 users in each group, totalling 4,000 educators.

Following an inspection of respondents' profiles, it was detected that in the group of high scorers a significant amount of users had earned points not for contributing often to the portal but because of having registered their children on the site (Users are occasionally awarded extra points for their birthday, to celebrate the New Year or at the beginning of the school year. Upon registration, they also receive extra points when they indicate they are a parent -for every child, they collect approximately 200 extra points. The logic behind these rewards is that these users will use KC both as a professional teaching tool, and as a tool to tutor their own children with homework or lessons.); consequently, their responses were excluded from analysis, together with 6 members of KC staff. The final sample consisted of 2,494 teachers: 2,097 female (84\%) and 397 male (16\%). Table 1 shows the spread of responses in the high and low groups according to their demographic characteristics.

Table 1: Demographic spread of responses

\begin{tabular}{lcccccccc}
\hline & \multicolumn{6}{c}{ Gender } & & \multicolumn{7}{c}{ Age } \\
& Female & Male & $<21 y$ & $21-30 y$ & $31-40 y$ & $41-50 y$ & $51-60 y$ & $>60 y$ \\
\hline $\begin{array}{l}\text { low group } \\
\mathrm{n}=2000\end{array}$ & $86 \%$ & $14 \%$ & $0 \%$ & $40 \%$ & $34 \%$ & $14 \%$ & $11 \%$ & $1 \%$ \\
$\begin{array}{l}\text { high group } \\
\mathrm{n}=494\end{array}$ & $76 \%$ & $24 \%$ & $0 \%$ & $15 \%$ & $31 \%$ & $30 \%$ & $22 \%$ & $2 \%$ \\
\hline
\end{tabular}

\section{Data analysis}

All analyses were performed with SPSS 21. Descriptive statistics (mean and standard deviation) were calculated. Independent samples t-tests were used to compare the mean scores of the high and low groups. To test the internal consistency of the subscale measuring teachers' motivation to share, we ran Cronbach's alpha; reliability was found to be satisfactory ( 8 items; $\alpha=.79$ ).

\section{Limitations}

A caveat to the research reported here should be borne in mind. To get feedback on the potential implementation of gamification mechanics, users were asked to give their opinion based on high fidelity mock-ups, but did not experience these features in real time. Also, although a quantitative approach has delivered robust findings on users' behaviour in an open repository, we believe this study could be further enhanced by qualitative research on participants' narrative insights into their open practices and motivations to share.

\section{Results}

\section{User activity on KlasCement}

Tables 2, 3 and 4 show how user activity is distributed in the low-scoring and high-scoring groups in terms of number of uploads to the repository, number of comments volunteered below resources, and number of scores awarded to other $\mathrm{KC}$ users. Unsurprisingly, contributions from 
teachers with the lowest scores are well below the level of activity of teachers in the high-scoring group. Accordingly, three quarters of users in the low-scoring group have never uploaded a resource, over half have never commented on resources, and a majority has never engaged in giving a score to a resource.

Table 2: Distribution of number of uploaded resources by group

\begin{tabular}{lcccccc}
\hline & \multicolumn{6}{c}{ Number of Uploads } \\
& 0 & 1 & $2-5$ & $6-10$ & $11-20$ & $>20$ \\
\hline $\begin{array}{l}\text { low group } \\
\mathrm{n}=2000\end{array}$ & $76 \%$ & $10 \%$ & $11 \%$ & $2 \%$ & $1 \%$ & $0 \%$ \\
$\begin{array}{l}\text { high group } \\
\mathrm{n}=494\end{array}$ & $35 \%$ & $6 \%$ & $15 \%$ & $11 \%$ & $13 \%$ & $19 \%$ \\
\hline
\end{tabular}

Table 3: Distribution of comments given by group

\begin{tabular}{lccccccccc}
\hline & \multicolumn{1}{c}{ Number of Comments } \\
& 0 & 1 & $2-5$ & $6-10$ & $11-20$ & $21-30$ & $31-50$ & $51-100$ & $>100$ \\
\hline $\begin{array}{l}\text { low group } \\
\mathrm{n}=2000\end{array}$ & $54 \%$ & $12 \%$ & $15 \%$ & $7 \%$ & $5 \%$ & $2 \%$ & $2 \%$ & $1 \%$ & $1 \%$ \\
$\begin{array}{l}\text { high group } \\
\mathrm{n}=494\end{array}$ & $35 \%$ & $6 \%$ & $15 \%$ & $11 \%$ & $13 \%$ & $8 \%$ & $5 \%$ & $4 \%$ & $2 \%$ \\
\hline
\end{tabular}

Table 4: Distribution of scores given by group

\begin{tabular}{lcccccccccc}
\hline & 0 & 1 & $2-5$ & $6-10$ & $11-20$ & $21-50$ & $51-100$ & $101-500$ & $501-1000$ & $>1000$ \\
\hline $\begin{array}{l}\text { low group } \\
\mathrm{n}=2000\end{array}$ & $66 \%$ & $9 \%$ & $9 \%$ & $8 \%$ & $5 \%$ & $2 \%$ & $1 \%$ & $0 \%$ & $0 \%$ & $0 \%$ \\
$\begin{array}{l}\text { high group } \\
\mathrm{n}=494\end{array}$ & $15 \%$ & $5 \%$ & $9 \%$ & $8 \%$ & $4 \%$ & $6 \%$ & $36 \%$ & $13 \%$ & $3 \%$ & $0 \%$ \\
\hline
\end{tabular}

Table 5 reports the mean and standard deviation for each activity by group. The large standard deviation of the high-scoring group compared to the low-scoring group indicates that teachers in the former category are different from each other more than their counterparts; while low scorers remain mostly inactive across activities, we find that high scorers' behaviour is less uniform: some contribute a lot, some less.

Table 5: Mean and SD per activity variable

\begin{tabular}{lccccccc}
\hline & Points & Logins & Viewed & Downloads & Uploads & Comments & Scores \\
\hline mean L & 181.99 & 232.33 & 950.74 & 871.12 & 0.73 & 5.86 & 6.13 \\
Mean H & 3542.78 & 395.18 & 1325.40 & 1140.81 & 12.40 & 42.23 & 236.78 \\
SD L & 104.27 & 184.41 & 435.09 & 429.94 & 2.08 & 19.95 & 24.36 \\
SD H & 1907.79 & 519.24 & 1369.70 & 1396.04 & 23.36 & 96.57 & 305.69 \\
\hline
\end{tabular}

\section{Perceived usefulness, ease of use and purpose}

Four statements were employed to measure how users of $\mathrm{KC}$ perceive its ease of use ("I find the website easy to use in general" and "I can easily find the materials I'm looking for") and its usefulness ("KC holds learning objects that suit my educational level and subject" and "I find $\mathrm{KC}$ useful in my work as a teacher"). No significant differences were observed between the two 
groups of teachers (see Table 6), which helps us to conclude that even though they demonstrate contrasting behaviours on $\mathrm{KC}$, they agree in finding the portal useful and easy to use.

Table 6: Perceived ease of use, usefulness and purpose of use ( $0=$ strongly disagree, $3=$ strongly agree)

\begin{tabular}{|c|c|c|c|c|}
\hline & \multirow[b]{2}{*}{$\begin{array}{c}\text { Overall } \\
\text { Mean (SD) }\end{array}$} & \multicolumn{3}{|c|}{ Groups } \\
\hline & & $\begin{array}{l}\text { Low } \\
\text { Mean (SD) }\end{array}$ & $\begin{array}{c}\text { High } \\
\text { Mean (SD) }\end{array}$ & $\begin{array}{c}\text { Sig. level } \\
\text { t-test }\end{array}$ \\
\hline $\mathrm{N}$ (low/high) & 538 & 338 & 200 & $\mathrm{~N} / \mathrm{A}$ \\
\hline I find the website easy to use in general & $2.42(.58)$ & $2.41(.59)$ & $2.44(.58)$ & $p=.69$ \\
\hline I can easily find the materials I' $m$ looking for & $2.22(.62)$ & $2.19(.63)$ & $2.27(.59)$ & $p=.18$ \\
\hline $\begin{array}{l}\text { KC holds learning objects that suit my } \\
\text { educational level and subject }\end{array}$ & $2.59(.57)$ & $2.60(.56)$ & $2.58(.58)$ & $p=.73$ \\
\hline I find $\mathrm{KC}$ useful in my work as a teacher & $2.71(.49)$ & $2.74(.48)$ & $2.67(.51)$ & $p=.13$ \\
\hline $\begin{array}{l}\text { I use KC primarily to find materials to build my } \\
\text { own lessons }\end{array}$ & $2.51(.58)$ & $2.57(.54)$ & $2.41(.63)$ & $p=.003$ \\
\hline I use KC primarily as a source of inspiration & $2.22(.67)$ & $2.25(.68)$ & $2.16(.66)$ & $p=.10$ \\
\hline $\begin{array}{l}\text { I use } \mathrm{KC} \text { to interact with colleagues and } \\
\text { broaden my professional network }\end{array}$ & $.99(.79)$ & $.97(.80)$ & $1.02(.78)$ & $p=.55$ \\
\hline
\end{tabular}

In relation to why teachers access $\mathrm{KC}$, results show that finding materials and inspiration to build lessons are a primary purpose, while interacting with colleagues and broadening one's professional network are hardly regarded as an important reason to visit the repository. These findings strongly suggest that teachers are fundamentally interested in KC as a library and not as a network, regardless of their level of engagement with the portal -note that there is no statistically significant difference between the low and high groups in interaction as purpose of use, and both responses lie close to the mean with almost the same SD. Therefore, even teachers who show generative behaviour do not see $\mathrm{KC}$ as a place to interact with a network of colleagues. The statistically significant difference that exists between the two groups may substantiate this outcome further: the higher valuation of the portal as a repository of resources by those who engage less fits in with a predetermined role: you come to a library not expected to bring your own books but to borrow them; as a user, not a contributor.

\section{Attitudes towards gamification/social networking features on KlasCement}

Table 7 displays how frequently $\mathrm{KC}$ users participate in the current social networking activities facilitated by the site. Analysis demonstrates that while they read comments and check out ratings, teachers hardly ever look at others' profiles, irrespective of scoring group. This stands as evidence that users of KC are only interested in its resources, not in each other. Presumably, they use scores and comments as representation of the quality of a resource, not as information about the user; their focus is on resources, not individuals.

Table 7: Networking activity $(0=$ never, $3=$ always $)$

\begin{tabular}{lcccc}
\hline & $\begin{array}{c}\text { Overall } \\
\text { Mean (SD) }\end{array}$ & $\begin{array}{c}\text { Low } \\
\text { Mean (SD) }\end{array}$ & $\begin{array}{c}\text { Groups } \\
\text { High } \\
\text { Mean (SD) }\end{array}$ & $\begin{array}{c}\text { Sig. level } \\
\text { t-test }\end{array}$ \\
\hline $\mathrm{N}$ (low/high) & 538 & 338 & 200 & $\mathrm{~N} / \mathrm{A}$ \\
$\begin{array}{l}\text { I look at other users' profiles } \\
\text { I read the comments below }\end{array}$ & $.68(.74)$ & $.59(.71)$ & $.85(.77)$ & $\mathrm{p}=.000$ \\
$\begin{array}{l}\text { learning objects } \\
\begin{array}{l}\text { l look at the rating of a learning } \\
\text { object }\end{array}\end{array}$ & $1.97(.79)$ & $1.90(.79)$ & $2.10(.77)$ & $\mathrm{p}=.005$ \\
\hline
\end{tabular}


Respondents' attitudes towards the addition of further gamification and social networking features on $\mathrm{KC}$ were found to be negative (Table 8). Teachers in this sample showed very little interest in learning about what other users are doing on the site ("In my view this is only useful in a kind of 'social environment' in which you form a group or circle with teachers of the same grade/subject") and felt strongly about having control over the privacy settings of their profiles. Statistically significant differences were observed between the low-scoring and high-scoring groups in their way of thinking about badges: in line with findings in the OECD (2007) report, those more likely to contribute their material to the repository seemed more partial to receiving a badge for their efforts than those unwilling to share resources. Notwithstanding the contrast, in the present sample neither group of respondents stood in complete agreement or disagreement, even if those against a reward system were louder to voice their concerns:

\section{"All that badges and ranking business does notbing for me. It annoys me rather than persuading me to do anything".}

"The badges will only encourage the giving of quick and unconsidered responses".

"T've posted and shared three things now, but I don't need a "badge" for this! If we can already do this unselfishly, then we will be encouraging a culture of greed even more; I will say "no thanks" and leave the site".

Likewise, the introduction of challenges as prompts to encourage sharing was rejected by survey respondents.

Table 8: Proposed gamification/social networked features ( $0=$ strongly disagree, $3=$ strongly agree $)$

\begin{tabular}{lcccc}
\hline & $\begin{array}{c}\text { Overall } \\
\text { Mean (SD) }\end{array}$ & $\begin{array}{c}\text { Low } \\
\text { Mean (SD) }\end{array}$ & $\begin{array}{c}\text { Groups } \\
\text { High } \\
\text { Mean (SD) }\end{array}$ & $\begin{array}{c}\text { Sig. level } \\
\text { t-test }\end{array}$ \\
\hline $\begin{array}{l}\mathrm{N} \text { (low/high) } \\
\text { I would like to see which learning objects }\end{array}$ & 538 & 338 & 200 & $\mathrm{~N} / \mathrm{A}$ \\
$\begin{array}{l}\text { a user has downloaded } \\
\text { It is important for me to be able to } \\
\text { choose whether my profile shows the }\end{array}$ & $2.27(.87)$ & $.67(.67)$ & $.71(.72)$ & $\mathrm{p}=.53$ \\
$\begin{array}{l}\text { learning objects I downloaded } \\
\text { I would like a badge indicating that I }\end{array}$ & $1.40(.88)$ & $1.27(.81)$ & $1.62(.96)$ & $\mathrm{p}=.000$ \\
$\begin{array}{l}\text { share resources } \\
\begin{array}{l}\text { A challenge like 'Give five comments to } \\
\text { receive a commentator-badge' would } \\
\text { stimulate me to do so }\end{array}\end{array}$ & $1.00(.84)$ & $1.01(.85)$ & $.98(.82)$ & $\mathrm{p}=.65$ \\
\hline
\end{tabular}

\section{Motivation to share on KlasCement}

The majority of responses obtained reflect that teachers are mainly willing to share resources in $\mathrm{KC}$ in fulfilment of mastery goals (Table 9); that is to say, they value the availability of feedback and they aim above all to do well as teachers. Extrinsic elements of motivation figure notably, demonstrating a certain degree of self-interest manifested in teachers' desire to receive praise from their peers and physical rewards in exchange for their knowledge. However, users shun recognition when derived from performance goals, i.e. the popularity of resources in a leader board or career opportunities; the aspiration to show oneself as a leader, or take top spot in competition with others, are regarded as dysfunctional mechanisms to promote sharing. Hence, we hypothesize that this type of behaviour represents, in teachers' eyes, a boastful display, which 
may explain their rebuttal of a badging system among the social networking components of the portal. The difference across all variables to the advantage of those in the high group indicates that teachers who are already contributing to $\mathrm{KC}$ are better disposed to increase their level of engagement in the future than those currently less active.

Table 9: Motivation to share $(0=$ strongly disagree, $3=$ strongly agree $)$

\begin{tabular}{|c|c|c|c|c|}
\hline I am stimulated to share on KlasCement when... & $\begin{array}{c}\text { Overall } \\
\text { Mean } \\
\text { (SD) }\end{array}$ & $\begin{array}{c}\text { Low } \\
\text { Mean } \\
(\mathrm{SD})\end{array}$ & $\begin{array}{l}\text { Groups } \\
\text { High } \\
\text { Mean } \\
\text { (SD) }\end{array}$ & $\begin{array}{l}\text { Sig. level } \\
\text { t-test }\end{array}$ \\
\hline $\begin{array}{l}\text { I get valuable feedback on my resources to improve them } \\
\text { (Mastery) }\end{array}$ & $\begin{array}{l}1.95 \\
(.69)\end{array}$ & $\begin{array}{l}1.85 \\
(.68)\end{array}$ & $\begin{array}{l}2.13 \\
(.68)\end{array}$ & $p=.000$ \\
\hline $\begin{array}{l}\text { I can view the popularity of my contributions in a leader } \\
\text { board (Performance) }\end{array}$ & $\begin{array}{l}1.35 \\
(.82)\end{array}$ & $\begin{array}{l}1.25 \\
(.79)\end{array}$ & $\begin{array}{l}1.53 \\
(.85)\end{array}$ & $p=.000$ \\
\hline $\begin{array}{l}\text { It can lead to interesting career opportunities (i.e. giving } \\
\text { workshops) (Performance) }\end{array}$ & $\begin{array}{l}1.20 \\
(.91)\end{array}$ & $\begin{array}{l}1.10 \\
(.87)\end{array}$ & $\begin{array}{l}1.36 \\
(.96)\end{array}$ & $p=.002$ \\
\hline $\begin{array}{l}\text { I am able to collaborate with other teachers (Social } \\
\text { solidarity) }\end{array}$ & $\begin{array}{l}1.69 \\
(.75)\end{array}$ & $\begin{array}{l}1.62 \\
(.76)\end{array}$ & $\begin{array}{l}1.81 \\
(.70)\end{array}$ & $p=.006$ \\
\hline $\begin{array}{l}\text { I am well informed about how many teachers I've helped } \\
\text { by sharing my resources (Social solidarity) }\end{array}$ & $\begin{array}{l}1.50 \\
(.81)\end{array}$ & $\begin{array}{l}1.44 \\
(.81)\end{array}$ & $\begin{array}{l}1.62 \\
(.82)\end{array}$ & $p=.015$ \\
\hline $\begin{array}{l}\text { I get a lot of likes and positive comments by other users } \\
\text { (Extrinsic) }\end{array}$ & $\begin{array}{l}1.77 \\
(.85)\end{array}$ & $\begin{array}{l}1.69 \\
(.84)\end{array}$ & $\begin{array}{l}1.91 \\
(.84)\end{array}$ & $p=.004$ \\
\hline $\begin{array}{l}\text { I can exchange the KC-points that I earn for an actual } \\
\text { prize (i.e. books) (Extrinsic) }\end{array}$ & $\begin{array}{l}1.74 \\
(.98)\end{array}$ & $\begin{array}{l}1.67 \\
(.96)\end{array}$ & $\begin{array}{l}1.86 \\
(.99)\end{array}$ & $p=.031$ \\
\hline $\begin{array}{l}\text { Because this extra effort makes me feel a professional } \\
\text { teacher (Mastery) }\end{array}$ & $\begin{array}{l}1.97 \\
(.83)\end{array}$ & $\begin{array}{l}1.91 \\
(.79)\end{array}$ & $\begin{array}{l}2.08 \\
(.88)\end{array}$ & $p=.032$ \\
\hline
\end{tabular}

\section{Discussion and conclusion}

The purpose of this research was to gain greater understanding of how teachers using an open repository of educational materials (KlasCement) perceive, and engage with, the portal's social network features, and to inquire into their attitudes towards the incorporation of further gamification elements to promote engagement. Our findings show that teachers do not generally look at each other's profiles and value having control over the information hither displayed; they read comments on a resource and pay attention to its ratings, thus cementing an interest in the resource itself, not the person behind it. This leads to our conclusion that they do not see $\mathrm{KC}$ as a social network but as a library of resources. These results reinforce a previous study of KC's usability as a website "primarily used to search for and download material, rather than for sharing material and information" (Pynoo et al., 2012; p.1308). Teachers' receptive rather than generative behaviour on KlasCement confirms its effectiveness as a virtual warehouse for content, where knowledge is stored (Atenas \& Havemann, 2013), but disputes the same authors' claim that quality repositories are places for communities of practice to interact. It is not interaction with peers that teachers seek when accessing KC, but resources to prepare for their lesson.

In addition, we learned that teachers share their knowledge in $\mathrm{KC}$ not to fulfil a desire to show off or be highly regarded by their peers, but because they believe sharing is the right thing to do as teachers. This supports McLure Wasko and Faraj's (2000) proposal that knowledge should be managed as a public good and communities of practice built on a moral obligation to share rather than on self-interest. Therefore, it does not come as a surprise that, when game mechanics were presented to users as a trigger for extrinsic rewards, as is the case in this study, they were generally rejected. What remains to be examined, in light of these findings, is whether the 
implementation of gamification to encourage users of open repositories to contribute and not merely consume resources, can instead be grounded on teachers' need for professional development.

\section{References}

1. van Acker, F., van Buuren, H., Kreijns, K., \& Vermeulen, M. (2013). Why Teachers Share Educational Resources: A Social Exchange Perspective. In R. McGreal, W. Kinuthia \& Stewart Marshall (Eds.), Open Educational Resources: Innovation, Research and Practice (pp. 177192). Commonwealth of Learning and Athabasca University.

2. de los Arcos, B., \& Weller, M. (in press). A Tale of Two Globes: Exploring the North/South Divide in Engagement with OER. In U. Herb \& J. Schöpfel (Eds.), Open Divide? Critical Studies on Open Access. Sacramento, CA: Litwin Books, LLC.

3. Atenas, J., \& Havemann, L. (2013). Quality assurance in the open: an evaluation of OER repositories. The International Journal for Innovation and Quality in Learning, 1(2), 22-34. Retrieved from http://eprints.soas.ac.uk/17347/

4. Atenas, J., Havemann, L., \& Priego, E. (2014). Opening teaching landscapes: The importance of quality assurance in the delivery of open educational resources. Open Praxis, 6(1), 29-43. Retrieved from http://openpraxis.org/index.php/OpenPraxis/article/view/81

5. Borthwick, K., Millard, D., \& Howard, Y. (2011). Report: HumBox Impact Analysis. Retrieved from

http://microsites.oii.ox.ac.uk/tidsr/sites/microsites.oii.ox.ac.uk.tidsr/files/humboximpactan alysisv2.pdf

6. Clements, K., Pawlowski, J., \& Manouselis, N. (2015). Open educational resources repositories literature review - Towards a comprehensive quality approaches framework. Computers in Human Behavior, 51(B), 1098-1106.

7. Comas-Quinn, A., \& Fitzgerald, A. (2013). Open Educational Resources in Language Teaching and Learning. York: Higher Education Academy (HEA). Retrieved from http://oro.open.ac.uk/37550/2/874A675B.pdf

8. Comas-Quinn, A., Beaven, T., Pleines, C., Pulker, H., \& de los Arcos, B. (2011). Languages Open Resources Online (LORO): Fostering a culture of collaboration and sharing. The EuroCALL Review, 18. Retrieved from http:/ / eurocall.webs.upv.es/index.php? $\mathrm{m}=\mathrm{menu} 00 \& \mathrm{n}=$ news_18\#loro

9. Dicheva, D., Dichev, C., Agre, G., \& Angelova, G. (2015). Gamification in Education: A Systematic Mapping Study. Educational Technology \& Society, 18(3), 75-88.

10. Domínguez, A., Saenz-de-Navarrete, J., de-Marcos, L., Fernández-Sanz, L., Pagés, C., \& Martínez-Herráiz, J. J. (2013). Gamifying learning experiences: Practical implications and outcomes. Computers and Education, 63, 380-392.

11. Fogg, B.J. (2009). A Behavior Model for Persuasive Design. Proceedings of the $4^{\text {th }}$ international conference on persuasive technology. New York, NY, USA: ACM. Retrieved from https://bjfogg.com/fbm_files/page4_1.pdf

12. Hamari, J., Koivisto, J., \& Sarsa, H. (2014). Does Gamification Work? - A Literature Review of Empirical Studies on Gamification. Proceedings of the $201447^{\text {th }}$ Hawaii International Conference on System Science, 3025-3034. Retrieved from http://people.uta.fi/ kljuham/2014hamari_et_al-does_gamification_work.pdf 
13. McInerney, D. M. \& Ali, J. (2016). Multidimensional and Hierarchical Assessment of School Motivation: Cross-cultural validation. Educational Psychology, 26(6), 717-734.

14. McInerney, D. M., Roche, L. A., McInerney, V., \& Marsh, H.W. (1997). Cultural Perspectives on School Motivation: The Relevance and Application of Goal Theory. American Educational Research Journal, 34(1), 207-236.

15. McLure Wasko, M., \& Faraj, S. (2000). "It is what one does": why people participate and help others in electronic communities of practice. Journal of Strategic Information Systems, 9(2), 155173.

16. Nacke, L. E., \& Deterding, S. (2017). The maturating of gamification research. Computers in Human Behavior, Editorial, 1-5.

17. Organisation for Economic Co-operation and Development - OECD (2007). Giving Knowledge for Free: The Emergence of Open Educational Resources. Paris: OECD- Educational Resources Centre for Educational Research and Innovation. Retrieved from https://www.oecd.org/edu/ceri/38654317.pdf

18. Phalachandra, B., \& Abeywardena, I.S. (2016). Open Educational Resources in the Commonwealth 2016. Burnaby, Canada: Commonwealth of Learning. Retrieved from https://www.researchgate.net/publication/310327477_Open_Educational_Resources_in_th e_Commonwealth_2016

19. Pynoo, B., Tondeur, J., van Braak, J., Duyck, W., Sijnave, B., \& Duyck, P. (2012). Teachers' acceptance and use of an educational portal. Computers \& Education, 58(4), 1308-1317.

20. Sabourin, J., Kosturko, L., \& McQuiggan, S. (2014). Teacher Usage Behaviours within an Online Open Educational Resource Repository. Proceedings of the first ACM conference on Learning @ scale conference (L@S '14). New York. NY, USA: ACM.

21. Tseng, F.-C., \& Kuo, F.-Y. (2014). A study of social participation and knowledge sharing in the teachers' online professional community of practice. Computers \& Education, 72, 37-47.

22. Zourou, K. (2016). Social networking affordances for open educational language practice. ALSIC (Apprentissage des langues et Systèmes d'Information et de Communication), 19. Retrieved from https://alsic.revues.org/2903

23. Zourou, K., \& Lamy, M-N. (2013). Social networked game dynamics in web 2.0 language learning communities. ALSIC (Apprentissage des langues et Systèmes d'Information et de Communication), 16. Retrieved from https://alsic.revues.org/2642

\section{Acknowledgements}

The authors would like to acknowledge the contribution of Katerina Zourou in building the research instrument. We would also like to thank Piet van den Bossche and Sven de Maeyer for their valuable feedback, and the European Commission for their financial support. 